\title{
Application of the Younger Abstention Doctrine to International Child Abduction Claims
}

\author{
Carl Rowan Metz†
}

When a parent from a foreign country believes that his or her child has been abducted and brought to the United States, there is a clear statutory remedy. The International Child Abduction Remedies Act ("ICARA"),' a federal law enacted to implement an international treaty, permits the parent to file a petition in either state or federal court for the child's return. Following a determination of whether the child was wrongfully removed or retained away from her habitual residence, the court can issue an order returning the child to her home.

A primary goal of the treaty, formally known as the Hague Convention on the Civil Aspects of International Child Abduction ("Hague Convention"), is to prevent an abducting parent from receiving a procedural advantage in a custody dispute by choosing the forum in which the child's future custody will be litigated. ICARA provides the framework for achieving this goal in the United States: Parents alleging an abduction and seeking the return of their children are given the right to choose whether a federal court or a state court will hear their abduction claim. If the ICARA petitioner succeeds, the child will be returned to her rightful home, and that nation's courts will have the authority to resolve the custody dispute.

In some of these cases, two independent claims go forward. In state court the alleged abductor files for custody of a child creating a state custody proceeding. In state or federal court the other parent files a claim under ICARA alleging that the custody proceeding should not go forward because the child was the subject of an international abduction. ${ }^{3}$ Under the terms of the Hague Convention, the state custody proceeding will be halted until the abduction claim is resolved.

$\dagger$ B.A. 2000, Northwestern University; J.D. Candidate 2003, The University of Chicago.

1 Pub L No 100-300, 102 Stat 437-42 (1988), codified at 42 USC $\$ \S 11601-10$ (1994 \& Supp 1998).

2 The Hague Convention on the Civil Aspects of International Child Abduction, TIAS No $11670(1980)$.

3 See 42 USC $\$ 11603$ (a)-(b) (1994). 
Several recent district court decisions have jeopardized the availability of the federal forum for ICARA claims. As this line of cases stands today, an ICARA petitioner finds the door to federal court closed so long as the alleged abductor has filed for custody of the child in state court. District courts are applying the abstention doctrine of Younger v Harris, , which employs principles of federalism to preclude federal courts from interfering with pending state proceedings, to bar the hearing of ICARA claims in federal court. This forces an ICARA petitioner to seek relief in state court.

This line of cases is troubling. First, other instances of Younger abstention offer only weak support for applying the doctrine in this context. Second, and more importantly, the cases fail to recognize the extent to which they broaden the federal abstention doctrine. Younger abstention is normally justified by the notion of federalist comity, which requires federal courts to respect state court processes to a degree that prevents them from unduly interfering with those processes, and to refrain from using their equitable powers in a way that injures the states. It is a rule of deference that prevents litigants from using the federal court system as an alternative to defending an ongoing state proceeding.

Abstention in ICARA cases represents something markedly different. It is the application of these same principles to hold that federal courts cannot interfere with state activities even if Congress specifically instructs them to do so. Such a power not only exceeds the authority claimed by the Supreme Court in its Younger line of cases, it is unnecessary to the promotion of federalism. Congress can protect the interests of federalism as well as the courts. Although rare, some statutory rights, including those found in ICARA, are created for the purpose of interfering with a state process. When federal courts have reason to believe that this is the case, it is inappropriate for them to abstain without considering the extent to which their action frustrates congressional intent. ${ }^{6}$

Additionally, abstention in ICARA cases does not provide the benefits that have justified previous applications of the Younger doc-

4 An ICARA claim is also referred to in this Comment, and in the case law, as a Hague petition. The distinction is immaterial for the purposes of this Comment. It should be noted only that a Hague petition is filed with the State Department, which is designated as the U.S. Central Authority for purposes of the treaty. An ICARA claim is the legal action brought in a district court. See also Exec Order No 12648, 53 Fed Reg 30637 (1988) (designating "the Department of State as the Central Authority of the United States for purposes of the Hague Convention on the Civil Aspects of International Child Abduction").

5401 US 37 (1971).

6 Part III.B argues that courts should consider such a congressional intent to exist if the regular operation of a statute has the tendency to interfere with a state process, and a provision conferring federal court jurisdiction is included in the same statute. 
trine. Whether the ICARA claim is heard in federal or state court, the custody dispute will be enjoined until the abduction claim is resolved. This means that federal courts lack a significant reason to defer to an ongoing custody dispute in state court, because that proceeding will be stayed regardless of which court hears the abduction claim.

Part I of this Comment discusses (A) the Younger abstention doctrine, (B) The Hague Convention, and (C) ICARA. Part II analyzes six cases in which federal district courts have applied the Younger doctrine to conclude that abstention is appropriate. Part III argues that such an application of Younger to ICARA cases violates the two underlying justifications of the doctrine and should be abandoned. These cases ignore Congress's ability to determine for itself whether a statutory right upsets the balance of federalism. Further, the interest of comity, a fundamental justification of the Younger doctrine, is only marginally served when the federal claim could not have been raised within the confines of the state proceeding.

\section{BACKGROUND LAW}

To understand why courts should not abstain under Younger in ICARA cases, it is first necessary to understand how these legal concepts operate independently. This Part introduces the Younger abstention doctrine, the Hague Convention, and ICARA.

\section{A. The Younger Abstention Doctrine}

In Younger $v$ Harris, the Supreme Court laid the groundwork for what is now known as the Younger abstention doctrine. The State of California indicted John Harris under a law that he believed violated the First Amendment. ${ }^{8}$ Rather than raise the statute's constitutional defect as a defense in his state trial, Harris filed a separate action as a plaintiff in federal court. He sought to have the statute invalidated and the State's prosecution of him enjoined. The Supreme Court held that a federal court could not provide this kind of injunctive relief absent a showing that the state court would be inadequate to address

7 To limit the scope of this argument, it is worth recognizing three other criticisms that could be advanced against this line of cases, but that this Comment does not adopt. First, the Comment does not contend that state courts would be unfair to ICARA petitioners who would prefer to be in federal court, or that alleged abductors would gain a procedural advantage by being in state court. This Comment assumes that state courts would be as fair and competent as federal courts in their resolution of ICARA claims. Second, this Comment does not argue that federal courts must have jurisdiction over ICARA claims in order for the United States to be in compliance with the Hague Convention. Third, the Comment does not argue that abstention in ICARA cases encourages the type of forum shopping that the Hague Convention was designed to prevent.

8 See 401 US at 38-39.

9 See id. 
Harris's constitutional claims, or that the prosecution was initiated in bad faith. ${ }^{10}$

The Supreme Court decided Younger solely on policy grounds." The decision relied on "comity," defined by the Court as "a proper respect for state functions ... and a continuance of the belief that the National Government will fare best if the States and their institutions are left free to perform their separate functions in their separate ways." ${ }^{12}$ As Younger noted, this concept is commonly referred to as "Our Federalism."."

The Court explained that Congress had consistently exhibited a desire to keep state courts free from federal court interference. ${ }^{14}$ Our government operates as "a system in which there is sensitivity to the legitimate interests of both State and National Governments." $\mathrm{Al}$ though the federal government is anxious to protect federal rights and interests, it must seek to do so "in ways that will not unduly interfere with the legitimate activities of the States." ${ }^{, 16}$ By filing an action in federal court to enjoin the California state court proceedings, Harris sought an improper form of relief, one to which he was not entitled so long as he could raise the same claims in state court. ${ }^{17}$

The Supreme Court has expanded the Younger doctrine to encompass civil proceedings as well as criminal ones. Under the Court's current jurisprudence, Younger requires a federal court to abstain from an exercise of jurisdiction if doing so would interfere with a state proceeding that: (1) is ongoing, (2) implicates an important state interest, and (3) provides an adequate opportunity to raise constitutional challenges.

Although the state's interest in civil cases can be demonstrated by showing a similarity to criminal proceedings, ${ }^{19}$ that need not always

10 See id at 53-54.

11 See id at 55 (Stewart concurring).

12 Id at 44. Elsewhere, comity is defined as "courtesy among political entities ... involving especially mutual recognition of legislative, executive and judicial acts." Black's Law Dictionary 261 (West 7th ed 1999). It is "kindly courteous behavior," "friendly civility," and "mutual consideration between, or as if between, equals." Webster's Third New International Dictionary 455 (Merriam-Webster 1986).

13401 US at 44.

14 See id at 43.

15 Id at 44 .

16 Id.

17 See id at 49.

18 See Middlesex County Ethics Committee v Garden State Bar Association, 457 US 423, 432 (1982) (holding that state bar disciplinary hearrings implicate an important state interest as well as the opportunity to raise constitutional challenges, and are thus legitimately the subject of Younger abstention).

19 See id at 432, citing Huffman $v$ Pursue, Ltd, 420 US 592, 604-05 (1975) (holding that a district court should have abstained from exercising jurisdiction over a claim that sought injunctive relief from Ohio's enforcement of obscenity laws). 
be the case. A strong state interest can also be demonstrated by showing that the proceedings are necessary either to vindicate important state policies or for the operation of the state judicial system. ${ }^{20}$ This latter conception of a state interest justifies abstention in cases in which the state is not a party to the civil suit at issue. ${ }^{21}$ Nonetheless, federal courts have a virtually unflagging obligation to adjudicate claims within their jurisdiction, and abstention remains "the exception, not the rule."22

The Younger doctrine has been applied to a wide variety of state proceedings, but one in particular is relevant to ICARA cases. In Moore v Sims, ${ }^{23}$ the Supreme Court applied Younger where a federal district court enjoined the Texas Department of Human Resources from seeking emergency protective custody over three children allegedly abused by their parents. ${ }^{24}$ Rather than challenge the agency's action in state court, the parents became plaintiffs in federal court and sought to have parts of the Texas Family Code declared unconstitutional.

The case is noteworthy because, in holding that the district court should have abstained, the Court stated that "[f]amily relations are a traditional area of state concern." ${ }^{26}$ The district court had acknowledged an important state interest in quickly removing abused children from their homes, but it had erroneously concluded that the importance of this interest suggested abstention was inappropriate. ${ }^{27}$

B. The Hague Convention

The Hague Convention on the Civil Aspects of International Child Abduction was adopted in 1980 in order to "protect children internationally from the harmful effects of their wrongful removal or re-

20 See Middlesex, 457 US at 432. See also Juidice $v$ Vail, 430 US 327, 335 (1977):

A State's interest in the contempt process ... is surely an important interest. Perhaps it is not quite as important as is the State's interest in the enforcement of its criminal laws .... or even its interest in the maintenance of a quasi-criminal proceeding .... But we think it is of sufficiently great import to require application of the principles of [Younger and Huffman].

21 See, for example, Pennzoil Co v Texaco, Inc, 481 US 1, 12-13 (1987) ("This Court repeatedly has recognized that the States have important interests in administering certain aspects of their judicial systems.").

22 New Orleans Public Service, Inc v Council of the City of New Orleans, ("NOPSI'), 491 US 350, 359 (1989) (noting that the areas in which abstention applies are "carefully defined" and holding that Younger abstention does not require deference to state proceedings reviewing legislative or executive action), quoting Deakins v Monaghan, 484 US 193, 203 (1988); Colorado River Water Conservation District v United States, 424 US 800, 813 (1976).

23442 US 415 (1979).

24 See id at 419.

25 See id at 419-21.

26 Id at 435.

27 See id at 434-35. 
tention and to establish procedures to ensure their prompt return to the State of their habitual residence." ${ }^{, 28}$ The removal or retention of a child is considered to be wrongful under the treaty when it breaches the non-abducting parent's custody rights, so long as those rights are being exercised at the time of the abduction. If a court determines that a child under its jurisdiction has been wrongfully removed or retained, it "shall order the return of the child forthwith."

By creating a civil remedy for abduction that is separate and distinct from custody proceedings, the Convention seeks to regulate international child abduction in two ways. First, the treaty makes it less likely that an abducting parent can use the abduction to gain a procedural advantage in a custody dispute. A primary purpose of the treaty, therefore, is "to preserve the status quo and to deter parents from crossing international boundaries in search of a more sympathetic court." "i1 The Convention attempts to prevent an abducting parent from establishing artificial legal connections with a forum that the abductor considers to be more favorable than the courts in the child's natural home. ${ }^{32}$ Second, by returning an abducted child to her habitual residence as soon as it is determined that an abduction occurred, the Convention seeks to minimize the harmful effects of these abductions. $^{33}$

\section{ICARA}

Congress enacted ICARA in 1988 to implement the Hague Convention in the United States. The statute has very little independent content. It creates a procedural framework for filing Hague petitions in the United States ${ }^{34}$ and defines certain terms, ${ }^{35}$ but does not otherwise address the substantive content of the Convention. "The provisions of [ICARA] are in addition to, and not in lieu of, the provisions

28 Hague Convention at Preamble (cited in note 2).

29 See id at Art 3(a)-(b).

30 Id at Art 12.

31 Friedrich v Friedrich ("Friedrich $I$ "), 983 F2d 1396, 1400 (6th Cir 1993) (reversing the district court's determination that a German father had terminated his custody rights when he "unilaterally expelled" his wife and child from their home).

32 See Elisa Perez-Vera, Explanatory Report: Hague Conference on Private International Law ("Perez-Vera Report"), in 3 Acts and Documents of the Fourteenth Session 426, II 14-15 (1980). The State Department has adopted the Perez-Vera Report as "the official history and commentary on the Convention" and uses it as a "source of background on the meaning of the provisions of the Convention." Department of State, Hague International Child Abduction Convention: Text and Legal Analysis, 51 Fed Reg 10494, 10503 (1986). See also Mozes v Mozes, 239 F3d 1067, 1069 n 3 (9th Cir 2001); Blondin v Dubois, 189 F3d 240,246 n 5 (2d Cir 1999).

33 See Perez-Vera Report at 123 (cited in note 32).

34 See 42 USC $\$ 11603$ (1994) (providing rules on jurisdiction, notice to parties, burdens of proof, and the manner in which petitions are to be filed).

35 See 42 USC \$ 11602 (1994). 
of the Convention.".35 Courts are therefore instructed to "decide the case in accordance with the Convention., ${ }^{37}$

One issue that the Hague Convention leaves unresolved, and that Congress accordingly addresses in ICARA, is the assignment of appropriate courts to hear Hague petitions. This omission results from the variety of the legal systems that the Convention seeks to accommodate. Each nation must therefore designate an appropriate court within its legal system. ${ }^{39}$ ICARA addresses this by granting both state and federal courts concurrent original jurisdiction over Hague petitions."

ICARA is not only geared towards remedying abductions that occur in violation of an existing custody order. The Convention explicitly provides that custody proceedings are to be suspended until the abduction claim has been resolved." ICARA makes this even more clear by declaring that the terms "wrongful removal" and "wrongful retention" apply equally to an abduction that occurs before a custody order has been entered. ${ }^{42}$ As courts have since found, many of the cases brought under ICARA involve parents who are actively involved in a custody dispute for their children.

\section{ICARA CASES DISMISSED UNDER YOUNGER}

To date, few federal courts have been required to consider Younger's applicability to petitions brought under ICARA. Perhaps at first glance, the two seem unrelated. Younger is principally concerned with protecting the states' rights to pursue their legitimate activities. There is no tradition of state involvement in international child abduction cases.

3642 USC $\$ 11601$ (b)(2) (1994).

3742 USC $\$ 11603$ (d).

38 See Perez-Vera Report at II 44 (cited in note 32).

39 See id.

40 See 42 USC $\$ 11603$ (a) ("The courts of the States and the United States district courts shall have concurrent original jurisdiction of actions arising under the Convention.").

41 See Hague Convention at Art 16 (cited in note 2) ("[T]he judicial or administrative authorities of the Contracting State to which the child has been removed ... shall not decide on the merits of rights of custody until it has been determined that the child is not to be returned.").

4242 USC \& $11603(f)(2)$. There are two general scenarios in which ICARA and the Hague Convention will be applied. In the first, a parent unhappy with a final custody ruling from a foreign court abducts the child in order to attempt to evade the foreign court's order. In the second, a parent abducts his or her child before a court in the child's rightful home has had a chance to rule on which parent should have custody. The abduction in the latter scenario is motivated either by a desire to have the custody dispute litigated in an American court, rather than a foreign court, or by a desire to evade the rule of law completely.

43 See Blondin v DuBois, 189 F3d 240, 241-42 (2d Cir 1999) ("As with many Hague Convention cases, this matter involves a custody dispute between now-separated parents."). 
However, "[f]amily relations are a traditional area of state concern," ${ }^{, 4}$ and a state has an important interest in administering aspects of its judicial system. ${ }^{45}$ This interest conflicts with ICARA because the most significant consequence of a successful ICARA petition is the return of the child to her home country, an event that would terminate a state custody proceeding. Primarily on this basis, courts have invoked Younger in several recent ICARA cases ${ }^{47}$ to deny the petitioner a federal forum for the abduction claim.

\section{A. District Court Abstentions}

Grieve $v$ Tamerin ${ }^{48}$ provides a good example of a federal court's decision to abstain. Gad Grieve and Elisheva Tamerin married in Israel, had a child, and subsequently divorced. ${ }^{49}$ Grieve brought the child to New York for, he contended, a brief visit. ${ }^{50}$ Shortly thereafter, Tamerin followed. While there, she filed for custody of the child in New York state court, which she received pending further proceedings. ${ }^{\text {s1 }}$ Arguing that his ex-wife abducted their child under the terms of the Hague Convention, Grieve filed an ICARA petition that sought the child's return and a stay of the state proceedings. ${ }^{\mathrm{s}}$

According to the Grieve court, part one of the Younger test was clearly satisfied because there was an ongoing custody proceeding in state court. ${ }^{53}$ The court gave the second prong-the importance of the state's interest-only slightly more detailed attention. First, the court explained that the relevant interest is not in the outcome of the particular case, but rather in the importance of the generic proceedings to

44 Moore, 442 US at 435.

45 See Pennzoil Co $v$ Texaco, Inc, 481 US 1, 12-13 (1987) (requiring the federal district court to abstain from hearing constitutional claims when they were not first presented to the state court, and it was thus impossible to determine whether the state statutes and procedural rules at issue actually raised constitutional claims).

46 See Bouvagnet v Bouvagnet, 2001 US Dist LEXIS 17169, *6 (N D Ill) ("An order directing the return of the children to a foreign country would have the effect of enjoining the state proceeding."), revd, No 01-3928, slip op (7th Cir July 26, 2002), 2002 US App LEXIS 15079.

47 For ease of reference, this Comment refers to these as the ICARA abstention cases. This term collectively refers to the following cases: Cerit v Cerit, 188 F Supp 2d 1239 (D Hawaii 2002) (abstaining under the Younger doctrine from exercising jurisdiction over an ICARA claim); Bouvagnet, 2001 US Dist LEXIS 17169 (N D Ill); Grieve v Tamerin, 2000 US Dist LEXIS 12210 (E D NY); Silverman v Silverman, No 00-2274, slip op (D Minn Nov 13, 2000), revd, 267 F3d 788 (8th Cir 2001); Bowden v Sigg, No 2:99-CV-908-K, slip op (C D Utah Dec 22, 1999); Gerbatsch v Gerbatsch, No 99-CV-728-J, slip op (S D Cal July 7, 1999). But see Hazbun Escaf $v$ Rodriquez, 191 F Supp 2d 685, 692-94 (E D Va 2002) (rejecting a Younger challenge to federal jurisdiction).

482000 US Dist LEXIS 12210, *6-11 (E D NY) (dismissing an ICARA petition under Younger on the grounds that a custody proceeding was ongoing in state court).
49 Id at $* 1$.
50 Id at $* 2$.
51 Id.
52 Id at $* 3$.
53 See id at $* 7$. 
the state. ${ }^{54}$ The court also relied on Moore $v$ Sims $^{55}$ for the proposition that "states have a strong interest in domestic relations matters generally and child custody questions in particular."

For the third prong of the Younger test-the petitioner's opportunity to raise the same claims in state court-the court noted that ICARA vests concurrent jurisdiction in federal and state courts. ${ }^{7}$ This point, the district court argued, belied Grieve's claim that the purpose of the Hague Convention is to provide petitioners with an alternative to state courts that are predisposed to decide custody disputes themselves, and not transfer them abroad.s

These general arguments are found throughout the ICARA abstention cases. While the wording varies from case to case, the courts consistently establish the general proposition that child custody matters represent an important state interest and find that concurrent ICARA jurisdiction provides petitioners with an adequate remedy in state court. In addition, some courts cite other reasons to abstain. For example, the court in Silverman v Silverman ${ }^{60}$ noted that the state court had already awarded temporary custody to one parent, and expressed a reluctance to "enter conflicting orders." Additionally, the courts in Bouvagnet $v$ Bouvagnet ${ }^{62}$ and Cerit $v$ Cerit $^{63}$ both concluded that the state's interest is not just in the ongoing custody proceeding, but in the resolution of the ICARA petition as well. ${ }^{64}$

\section{B. Criticisms of These Decisions}

Even if the abstaining courts are correct in concluding that all three parts of the Younger test are met, there are several issues that they fail to address along the way. For instance, the courts do not ap-

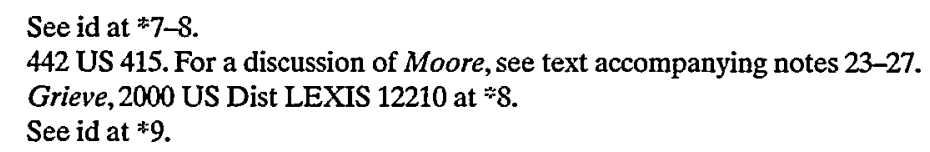

58 See id at * $8-9$. The court also argued that abstention was warranted because Grieve previously made the same Hague application in state court, thus availing himself of the state's jurisdiction. See id. Note, however, that two other courts used the ICARA petitioners' failure to do the same as a reason to abstain. See Bouvagnet v Bouvagnet, 2001 US Dist LEXIS 17169, *11 (N D Ill); Silverman v Silverman, No 00-2274, slip op at 7 (D Minn Nov 13, 2000), revd, 267 F3d 788 (8th Cir 2001).

59 See, for example, Bouvagnet, 2001 US Dist LEXIS 17169 at *4. But see Bowden $v$ Sigg, No 2:99-CV-908-K, slip op at 5 (C D Utah Dec 22, 1999) ("Neither the first nor the second [Younger] criteria are at issue here," in part because it is well settled that the state has a strong interest in domestic relations matters.).

60 No 00-2274, slip op (D Minn Nov 13, 2000), revd, 267 F3d 788 (8th Cir 2001).

61 Id at 7.

622001 US Dist LEXIS 17169 (N D Ill), revd, No 01-3928, slip op (7th Cir July 9, 2002), 2002 US App LEXIS 15079.

$63188 \mathrm{~F}$ Supp 2d 1239 (D Hawaii 2002).

64 See Cerit, 188 F Supp 2d at 1248; Bouvagnet, 2001 US Dist LEXIS 17169 at *10. 
pear to recognize that the state's interest in Moore was augmented because it was a party to the proceedings. In contrast, custody proceedings involve two private citizens in their roles as parents. An increased state interest also exists in custody cases when there are allegations of child abuse, due to the heavy involvement of the state in such cases. ${ }^{66}$ No such allegations are made in the cases at hand.

It is not surprising, therefore, that the ICARA abstention cases have received criticism from other courts. For instance, the most recent district court to consider the issue calls the abstaining courts "unpersuasive on their reasoning" and argues that to the extent they find a state interest in Hague petitions, they inappropriately disregard the fact that the abduction claim is decided without considering the merits of any underlying child custody claims. ${ }^{67}$

To date, three federal Circuit Courts have also considered this issue, with each finding abstention inappropriate. However, the courts adopt markedly different reasoning, and none of their opinions provide a clear rule that appears likely to be broadly applied to resolve abstention claims in other ICARA cases.

Grieve did not appeal the district court's application of Younger to his Hague petition. However, the Second Circuit Court of Appeals reviewed a later proceeding in the same dispute ${ }^{69}$ and voiced a criticism of the earlier decision to abstain:

A state plainly has an interest in the outcome of a child custody dispute adjudicated in its courts. Yet New York's resolution of a custody battle is not so bound up with the State's sovereign functions as to be "important" in the comity-related sense in which the Younger cases use the term.

The Second Circuit also explained that a strong federal interest in foreign relations, implicated by the enforcement of a treaty, weighs against abstention, as does the fact that the Hague Convention divests

65 See Moore, 442 US at 423.

66 See, for example, Brunken $v$ Lance, 807 F2d 1325, 1330 (7th Cir 1986) (holding that state involvement as a party in the judicial proceedings, and the state interest in protecting children who are suspected victims of abuse, both argue in favor of Younger abstention).

67 See Hazbun Escaf v Rodriquez, 191 F Supp 2d 685, 693 n 34 (E D Va 2002).

68 Compare Silverman v Silverman, 267 F3d 788, 792 (8th Cir 2001) (reversing the district court's decision to abstain because the requested relief was not discretionary), with Bouvagnet $v$ Bouvagnet, No 01-3928, slip op at 11-13 (7th Cir July 26, 2002), 2002 US App LEXIS, *15-21 (reversing district court's decision to abstain because federal plaintiff had not engaged in conduct that arguably violated state law, and because the state's important interest in adjudicating custody disputes was outweighed by a common federal interest in enforcing the Hague Convention) (withdrawn 2002 US App LEXIS 17954).

69 See Grieve $v$ Tamerin, 269 F3d 149, 152-53 (2d Cir 2001) (affirming the dismissal of an ICARA petition on collateral estoppel grounds after the father chose not to appeal the dismissal under Younger and instead brought an identical new action in the Eastern District of New York).

70 Id. 
a state court of jurisdiction to resolve custody issues until after the Hague claim has been resolved."

It should be noted, however, that this conclusion is based in no small part on the Second Circuit's earlier determination that the relevant question in Younger cases is whether "the state action concerns the central sovereign functions of state government." ${ }^{\text {"n }}$ It therefore cannot be assumed that other circuits would reach the same result.

Notwithstanding the Second Circuit's viewpoint, there is a reasoned basis for a federal court to conclude that states have a sufficiently strong interest in overseeing a private custody dispute to warrant abstention. One commentator, writing in a different context, suggests five functions of family law that represent important state interests. $^{3}$ A court could draw on these functions to suggest that the state has an interest in administering even the most basic, nonconfrontational custody case.

Although two other ICARA abstention cases were reversed on appeal, their reasoning differs from that of the Second Circuit, and it is not clear that either opinion can be broadly applied to other ICARA abstention cases. In Silverman $v$ Silverman, ${ }^{74}$ the Eighth Circuit considered whether it was erroneous for a federal court to abstain from hearing an ICARA claim on the ground that abstention permitted the alleged abductor to engage in the kind of forum shopping that the Hague Convention was intended to curtail. ${ }^{75}$ However, the court passed up the opportunity to address this claim. Instead, it reversed the decision to abstain on the ground that it was improper to abstain and dismiss the suit outright when the relief sought was not discretionary. ${ }^{76}$ The court then remanded the case for the district court to make a full determination of the abduction claim."

This approach does not directly resolve the issues in this Comment, however, because although it is impermissible to abstain and dismiss an action where the relief is not discretionary, it is permissible

71 See id at 153.

72 Id at 152, quoting Philip Morris, Inc v Blumenthal, 123 F3d 103, 106 (2d Cir 1997).

73 See Carl E. Schneider, Symposium: One Hundred Years of Uniform State Laws: Discretion, Rules, and Law: Child Custody and the UMDA's Best-Interest Standard, 89 Mich L Rev 2215, 2281-82 (1991) (arguing that the administration of a family law system fulfills state interests in protecting children, providing a means for resolving disputes, arranging legally binding terms of care and access for children, directing people towards the state's notion of the "best" forms of child custody, and emphasizing the responsibilities parents have for their children).

74267 F3d 788 (8th Cir 2001) (reversing the district court's decision to abstain and dismiss a Hague petition).

75 See id at 792.

76 Id ("[F]ederal courts have the power to dismiss or remand cases based on abstention principles only where the relief being sought is equitable or otherwise discretionary."), quoting Quackenbush v Allstate Insurance Co, 517 US 706, 731 (1996).

77 Id at 792 
for a court to abstain and stay the action. ${ }^{78}$ Therefore, the court was not required to act as it did in reinstating the cause of action in federal court. As a result, Silverman also fails to provide a rule of decision that other federal courts are likely to follow.

Shortly before this Comment was published, the Seventh Circuit released its opinion in Bouvagnet v Bouvagnet," holding that "a Hague petition simply does not implicate the Younger abstention doctrine., ${ }^{, 80}$ The court reached this conclusion by explaining that, notwithstanding the multi-factor test in Middlesex County Ethics Committee $v$ Garden State Bar Association, ${ }^{\text {s1 }}$ the Younger doctrine only applies when "the federal plaintiff ha[s] engaged in conduct actually or arguably in violation of state law, thereby exposing himself to an enforcement proceeding in state court." gaged in any such conduct, the Younger doctrine did not apply to his ICARA petition. ${ }^{8}$

In addition, the court reasoned that there was "an even more fundamental reason" that the Younger doctrine should not apply. Specifically, the court found that it was the failure of local jurisdictions to respect custody arrangements from foreign nations that had prompted the United States to assume, by treaty, an obligation to return $a b-$ ducted children to their habitual residence. Accordingly, although the individual states possess an "important" interest in settling custody disputes, this is outweighed by the "even more important" interest, shared collectively by all the states, in enforcing the strictures of the Hague Convention.s

The first rationale in Bouvagnet, that the federal plaintiff must have allegedly engaged in some form of misconduct before Younger

78 Quackenbush, 517 US at 730. See also 767 Third Avenue Associates v Consulate General of Socialist Federal Republic of Yugoslavia, 218 F3d 152, 163 (2d Cir 2000); Gross v Weingarten, 217 F3d 208, 224 (4th Cir 2000); Amerson v Iowa, 94 F3d 510, 512 (8th Cir 1996).

79 No 01-3928, slip op (7th Cir July 26, 2002), 2002 US App LEXIS 17661 (withdrawn 2002 US App LEXIS 17954).

80 Id at 13 . On July 22, 2002, four days before the court rendered its opinion, the parties filed a "Joint Notice of Settlement and Motion to Dismiss Appeal." Motion for Three-Day Extension to File Supplemental Statement of Appellant Patrice Bouvagnet Pursuant to the Court's July 29, 2002 Order, Bouvagnet v Bouvagnet, No 01-3928, *1 (7th Cir Aug 5, 2002). On July 29, three days after the opinion was released, the Seventh Circuit issued an order requiring the parties to clarify the basis of their settlement. See id at $* 2$. In response to this order, the appellee filed a motion asking the court to vacate its July 26th opinion. See id. The Seventh Circuit's opinion in Bouvagnet was subsequently withdrawn by the court. See 2002 US App LEXIS 17954, *2 (7th Cir Aug 29, 2002).

81457 US 423 (1982).

82 Bouvagnet, No 01-3928, slip op at 10, quoting Alleghany Corp v Haase, 896 F2d 1046, 1053 (7th Cir 1990), vacd as moot as Dillon v Alleghany Corp, 499 US 933 (1991).

83 See id at 11.

84 Id at 12-13.

85 Id at 13. 
applies, is only endorsed by the Seventh and Ninth Circuits, ${ }^{86}$ and as a result, does not resolve the issues in this Comment with a rule that is likely to be followed in other ICARA abstention cases. Moreover, the court does not explain whether its rule would permit abstention when the abduction is defended as an attempt to remove the children from an abusive home. ${ }^{87}$ The court's reliance on Moore ${ }^{88}$ suggests that such an allegation might permit abstention, ${ }^{89}$ creating an incentive for parents that seek abstention to allege abuse for jurisdictional reasons. In contrast, the court's second rationale, that there is a strong federal interest in enforcing the Hague Convention, is similar to one of the arguments in Grieve, and might form the basis of a more broadly applicable rule. ${ }^{\text {. }}$ However, this would likely require other Circuits to abandon or amend the multi-factor test they use to identify when Younger applies, because this test does not require courts to consider the weight of the federal interest involved." In addition, the Supreme Court has previously held that the mere assertion of a strong federal interest "will not alone compel the exercise of federal jurisdiction.","

\section{YOUNGER ABSTENTION IS INCONSISTENT WITH THE TYPE OF CLAIM PRESENTED IN ICARA CASES}

Part II explained that a federal court might reasonably conclude that all three prongs of the Younger test are met in an ICARA case: A state custody claim is ongoing; states have important interests in resolving custody disputes brought within their borders; and ICARA's grant of concurrent jurisdiction makes a state court fully capable of hearing the federal challenge. ${ }^{93}$ Although a few other courts have criticized these decisions, none have conclusively established a rule that is likely to be followed in all cases. Nevertheless, abstention in these cases represents a sharp break from established Younger cases. This departure should not be tolerated.

86 See id at $10 \mathrm{n} 2$, citing Green $v$ City of Tuscon, 255 F3d 1086, 1093-94 (9th Cir 2001). Even within these circuits, the misconduct test has only weak support. Of the three Seventh $\mathrm{Cir}$ cuit cases that reach this result, two are no longer binding authority within the Circuit: Allegheny was vacated as moot, 499 US 933, while Bouvagnet was withdrawn by the court. See 2002 US App LEXIS 17954. In addition, the Ninth Circuit provides for exceptions to this rule, finding in Green that Younger "ordinarily [ ] although not always" applies when the state dispute is an enforcement action against the federal plaintiff. Green, 255 F3d at 1094.

87 See, for example, Blondin v DuBois, 189 F3d 240, 242 (2d Cir 1999).

88 See generally Parts I.A and II.B.

s9 See Bouvagnet, No 01-3928, slip op at 11 n 3.

90 See Grieve, 269 F3d at 153.

91 See Middlesex, 457 US at 365.

92 New Orleans Public Service, Inc $v$ Council of the City of New Orleans, ("NOPSI"), 491 US 350, 365 (1989) (finding that the mere assertion of a federal interest in applying federal law over a preempted state statutes does not preclude abstention).

93 See text accompanying note 18 . 
This Part argues that in ICARA, Congress created a statutory cause of action, actively considered which courts would be appropriate to grant the relief at issue, and granted concurrent jurisdiction to state and federal courts. For these reasons, federal courts are not justified in invoking Younger in order to defeat Congress's intent.

A. The Decreased Emphasis on the Requirement That the Federal Claims Be Constitutional in Nature

There is no doubt that the Younger doctrine has evolved from its inception, ${ }^{94}$ and not merely because it currently applies in the civil context as well as the criminal. Take, for instance, the Supreme Court's 1977 characterization of the decision federal courts face in Younger cases:

[W] have frequently inquired into the proper role of a federal court, in a case pending before it and otherwise within its jurisdiction, when litigation between the same parties and raising the same issues is ... pending in a state court. More precisely, when a suit is filed in a federal court challenging the constitutionality of a state law under the Federal Constitution and seeking to have state officers enjoined from enforcing it, should the federal court proceed to judgment when it appears that the State has already instituted proceedings in the state court to enforce the challenged statute against the federal plaintiff and the latter could tender and have his federal claims decided in state court? ?s $^{\text {s }}$

Working from this definition, it would be hard to see how a federal court could abstain in an ICARA case. Nearly every critical feature can be distinguished. ICARA says that a federal court is not permitted to consider the same issues that would be raised in a custody dispute; there is no constitutional challenge; no state law is itself the subject of scrutiny; and the state is merely the forum, not a party. The only apparent similarity is that the same parties are involved in both the state and federal actions, and the federal action could have been brought in state court.

This, of course, suggests nothing more than the idea that an action brought under ICARA would have been a poor fit for the Younger

94 See, for example, Pennzoil Co v Texaco, Inc, 481 US 1, 30 n 2 (1987) (Stevens concurring) (listing the variety of state interests that were held sufficient to implicate Younger abstention from 1971 through 1986).

95 Trainor $v$ Hernandez, 431 US 434, 440 (1977).

96 See Blondin v DuBois, 189 F3d 240, 245 (2d Cir 1999) (explaining that under the Hague Convention, "a United States District Court has the authority to determine the merits of an abduction claim, but not the merits of the underlying custody claim"), quoting Friedrich v Friedrich ("Friedrich I"), 983 F2d 1396, 1400 (6th Cir 1993). 
doctrine as it was envisioned in 1977. Today, several circuit courts still apply the test that was formulated just five years later in Middlesex County Ethics Committee v Garden State Bar Association" with only modest variation. These courts have held that abstention is required when there is a state action that is (1) ongoing, (2) implicates important state interests, (3) and provides an adequate opportunity for the defendant to raise federal challenges." The important difference between this test, and the one used in Middlesex, is a substitution of the word "federal" for the word "constitutional." The effect of this change is to enlarge the pool of cases that Younger addresses. Cases presenting constitutional claims will still be included, but so will cases raising federal statutory claims.

Although it is unclear why this change occurred, it was not mandated by the Supreme Court's Younger jurisprudence. The Court has not directly addressed the Younger doctrine since its 1989 decision in New Orleans Public Service, Inc v Council of the City of New Orleans ("NOPSI")," and even there, the Court did not discuss whether the relevant test was limited to constitutional claims. ${ }^{101}$ Earlier decisions suggest that, after Middlesex, the relevant test was whether a petitioner's "constitutional" claims could be vindicated. ${ }^{102}$ In 1999, Justice Ginsburg echoed this position in a case that was not decided on Younger grounds. ${ }^{103}$

Additionally, the change is not universal; several circuit courts have recently decided Younger cases with reference to the "constitutional claims" test. ${ }^{104}$ Although this does not amount to a rejection of

97457 US 423 (1982). See text accompanying note 18.

98 See, for example, Tindall $v$ Schewe, 269 F3d 533, 538 (6th Cir 2001) (applying a test that has the same three requirements as Middlesex: an ongoing state action, the implication of important state interests, and an adequate opportunity to raise constitutional challenges); Grieve $v$ Tamerin, 269 F3d 149, 152 (2d Cir 2001) (same).

99 See, for example, Wolfe $v$ Ingram, 275 F3d 1253, 1267 (10th Cir 2002) (applying a test that uses the term "federal claims"); Green v City of Tuscon, 255 F3d 1086, 1091 (9th Cir 2001) (same).

100491 US 350 (1989).

101 See generally id at 364-73. See also Richard H. Fallon, Jr., The "Conservative" Paths of the Rehnquist Court's Federalism Decisions, 69 U Chi L Rev 429, 466-67 (2002) (arguing that by the end of the 1980s the Supreme Court had lost interest in significant further expansions of the Younger doctrine). The other case that has had a significant impact on the Court's Younger analysis was primarily decided with reference to the Burford abstention doctrine. See Quackenbush v Allstate Insurance Co, 517 US 706 (1996).

102 See, for example, Ohio Civil Rights Commission v Dayton Christian Schools, Inc, 477 US 619,627 (1986) (arguing that Younger applies to state administrative proceedings "so long as in the course of those proceedings the federal plaintiff would have a full and fair opportunity to litigate his constitutional claim").

103 See Reno v American-Arab Anti-Discrimination Committee, 525 US 471, 495 (1999) (Ginsburg concurring in part and concurring in the judgment) (explaining that the opportunity to vindicate constitutional claims is part of the test from Middlesex).

104 For example, the Third, Fifth, Sixth, Seventh, and Eleventh Circuits have all recently ap- 
the "federal claims" test by these circuits, it does suggest that a "federal claims" test is not a well-developed part of modern Younger analysis.

In most cases, the change to a "federal claims" test is likely to be insignificant. Younger is principally concerned with the promotion of federalism and comity, and to that end it seems largely irrelevant whether a federal plaintiff is using a constitutional claim or a statutory claim to disrupt state processes. The impairment of state interests appears to be the same in either case.

However, one feature of the change is significant. By including statutory claims in the Younger analysis, courts have left open the possibility that Congress created a cause of action in some cases with the purpose of permitting a federal plaintiff to disrupt an ongoing state process. In addition, Congress may, in some instances, have intended to let a plaintiff choose between federal and state courts to vindicate these rights. When such a situation occurs, it is unclear whether Younger should be applied. All of the material elements are the same: A federal court will be asked to disrupt an ongoing state process, even though the federal petitioner could vindicate the same rights in state court. However, it is no longer clear that such an interference is "undue"

The ICARA courts have failed to address the implications of this scenario in deciding to abstain. The plain language of the Hague Convention halts all action on the underlying custody dispute until the abduction claim has been resolved. ${ }^{107}$ This is an interruption in a state process, and in choosing to implement the treaty, Congress gave concurrent jurisdiction over ICARA claims to both federal and state courts. This forces courts to consider why Congress implemented the treaty in the way it did and whether this should factor into the abstention analysis. Part III.B of this Comment argues that there is significant evidence to suggest that the drafters of ICARA understood that state processes would be impaired. It further argues that nothing in the Supreme Court's Younger line of cases permits federal courts to disregard congressional judgment.

plied a version of the Younger test that was defined with reference to "constitutional claims." See, for example, Zahl v Harper, 282 F3d 204, 209 (3d Cir 2002); Armco, Inc v United Steelworkers of America, 280 F3d 669, 681 (6th Cir 2002); Green v Benden, 281 F3d 661, 666 (7th Cir 2002); Butler v Alabama Judicial Inquiry Commission, 245 F3d 1257, 1262 (11th Cir 2001); Wightman v Texas Supreme Court, 84 F3d 188, 189 (5th Cir 1996).

105 NOPSI, 491 US at 359.

106 Id, quoting Younger, 401 US at 45.

107 See Hague Convention at Art 16 (cited in note 2). See also Bouvagnet, No 01-3928, slip op at 12. ("ICARA ... contemplates that a successful action might well result in the displacement of a custody decision in the state to which the child wrongfully has been taken."). 
Only one of the district courts that abstained from an ICARA petition considered this issue, and the court's reasoning has little to do with the Younger doctrine itself. In Gerbatsch $v$ Gerbatsch, ${ }^{108}$ the court expressly found that it could abstain even though the petition does not raise constitutional claims. ${ }^{109}$ The court argued that it could take this position so long as the petition raises issues of state law with substantial public importance, a condition that it found present given the implications an ICARA case would have on future custodial decisions. However, to justify its ruling, the court cited an entirely different abstention doctrine, without explaining that doctrine's relevance to Younger."

Courts also apply a second and less controversial feature of Younger without exception: Younger should only be applied where the federal claims could have been raised in the state proceedings. This is the test that was formulated in Juidice $v$ Vail, ${ }^{\text {"II }}$ and which has been reaffirmed several times since. ${ }^{112}$ This requirement follows from the Court's conclusion that abstention is merely a decision to decline to grant certain kinds of equitable relief. ${ }^{113}$ If a federal claim can be brought as a defense to the pending state action, abstention has the effect of allowing that claim to be heard without causing an interruption in the state proceeding.

If, on the other hand, the federal right is one that can be brought in state court, but not in the currently pending state proceeding, there is no way to vindicate that right without bringing a separate cause of action. Abstention in such a circumstance does not prevent the pending state proceeding from being enjoined. It only means that it is enjoined pending the resolution of a separate state action, rather than a separate federal action.

10 No 99-CV-728-J, slip op at 7 (S D Cal July 7, 1999).

109 See id, citing Colorado River Water Conservation District v United States, 424 US 800, 814 (1976) (analyzing three different abstention doctrines).

110 See Colorado River, 424 US at 814. Gerbatsch supports its holding by quoting the Supreme Court's analysis of the Burford abstention doctrine and ignores the Court's separate analysis of Younger. See id at 814-16.

111430 US 327, 337 (1977) ("Here it is abundantly clear that appellees had an opportunity to present their federal claims in the state proceedings. No more is required to invoke Younger abstention.").

112 See Moore, 442 US at 425 ('The pertinent issue is whether appellees' constitutional claims could have been raised in the pending state proceedings.").

113 See, for example, Quackenbush v Alstate Insurance Co, 517 US 706, 726 (1996); NOPSI, 491 US at 359 (stressing that Congress's power to determine the courts' jurisdiction is set against a background in which the courts possess "discretion in determining whether to grant certain types of relief"). 
B. Younger Abstention Is Inappropriate if Congress Created the

Federal Cause of Action in Order to Interfere with

State Processes

When a plaintiff's cause of action reaches federal court through general federal question jurisdiction, there is no particular reason to think that such a claim should be maintainable in federal court at the expense of a parallel proceeding in state court. The Younger doctrine permits federal courts to abstain from hearing a case, even though jurisdiction is properly asserted, when the relief sought would unduly interfere with state processes. ${ }^{114}$ As Younger indicates, as long as the same claims could also be heard in the state proceeding, the federal court's decision to abstain serves the interests of federalism without diminishing a claimant's ability to seek relief.

This is the premise of Younger: Although courts do not define the scope of their own jurisdiction-a role constitutionally assigned to Congress - they do retain an inherent power to decline to grant certain forms of equitable relief that would unduly impair state processes. "15 This is done only as an exception to the "virtually unflagging" rule that federal courts have an obligation to adjudicate claims within their jurisdiction. ${ }^{16}$

Although there may be no reason to think that federal courts could not abstain when a cause of a action is statutory in nature-a development permitted by the lower courts' usage of the term "federal" in place of "constitutional" claims" -abstention from such claims raises the possibility that federal courts will abstain even in the face of a specific congressional decision that a particular interference with state processes is permissible. If no allowance is made for the possibility that the statutory cause of action was designed to interfere with a state process, the Younger doctrine has evolved into a check on Congress's authority to determine the scope of federal court jurisdiction. In such cases, Younger would prevent Congress from deciding that a federal court should interfere with a state process. While it might be reasonable to simply infer that a constitutional right was not designed to interfere with an ongoing state proceeding, a recently enacted statute might have just this purpose.

114 See Younger, 401 US at 44-45.

115 See Quackenbush v Allstate Insurance Co, 517 US 706, 726 (1996); NOPSI, 491 US at 359 (emphasizing the discretion courts retain in determining whether to authorize certain forms of equitable relief). But see Martin H. Redish, Abstention, Separation of Powers, and the Limits of the Judicial Function, 94 Yale L J 71, 76-79 (1984) (arguing that even a limited theory of abstention "could be characterized as a judicial usurpation of legislative authority, in violation of the principle of separation of powers").

116 NOPSI, 491 US at 359, quoting Deakins v Monaghan, 484 US 193, 203 (1988).

117 See Part III.A. 
The point is illuminated by the source of the authority courts claim for their abstention power: a level of discretion that is part of the common law background against which jurisdiction-conferring statutes are enacted. ${ }^{118}$ If this is recognized as a true common law background rule, it is subject to statutory revision, rendering it possible for Congress to vest federal court jurisdiction over causes of action from which the courts are not allowed to abstain. ${ }^{119}$ As long as the proposed relief is not discretionary, the Supreme Court has never claimed that its abstention powers extend so far as to allow it to second-guess Congress and to determine for itself when a grant of jurisdiction represents an affront to federalism. ${ }^{120}$ The relief ICARA provides-the return of the child - is in fact mandatory. ${ }^{121}$

This consideration is particularly important in light of the fact that the three-part test most commonly used to identify when Younger applies does not call on federal courts to balance the respective weights of state and federal interests to determine whether abstention is appropriate. If the state interest is compelling, the weight of the federal interest is irrelevant. ${ }^{12}$ In contrast, the members of Congress have the capacity to weigh the respective interests and determine whether federal involvement is appropriate.

The question for present purposes is whether the cause of action created by the United States's ratification of the Hague Convention and its implementation in ICARA is one from which federal courts cannot abstain. That is to say, courts should consider whether they have been instructed by Congress that abduction claims should be heard in federal court despite possible interference with a state process. ${ }^{123}$ There is considerable evidence that such a result was in fact in-

118 See NOPSI, 491 US at 359. See also Quackenbush, 517 US at 726; Fallon, 69 U Chi L Rev at 465 (cited in note 101) (stating that federal courts have long assumed the discretion to fine-tune open-ended jurisdictional grants).

119 See Rex E. Lee and Richard G. Wilkins, An Analysis of Supplemental Jurisdiction and Abstention with Recommendations for Legislative Action, 1990 BYU L Rev 321, 370 (proposing federal legislation that would limit the courts' Younger powers to criminal cases).

120 See Quackenbush, 517 US at 732 (Scalia concurring) ("There is no 'serious affront to the interests of federalism' when Congress lawfully decides to pre-empt state action-which is what our cases hold (and today's opinion affirms) Congress does whenever it instructs federal courts to assert jurisdiction over matters as to which relief is not discretionary."), quoting id at 733 (Kennedy concurring).

121 See Hague Convention at Art 12 (cited in note 2). See also Silverman, 267 F3d at 792.

122 See Middlesex, 457 US at 432 (suggesting that federal courts may hear a claim in spite of a state interest only when the constitutional claim could not be heard in the state proceeding). This conflicts with the Seventh Circuit's conclusion in Bouvagnet that a strong federal interest makes abstention inappropriate. See Bouvagnet, No 01-3928, slip op at 13. However, in Bouvagnet, the court openly expressed doubt as to whether the Middlesex test had taken "on a life of its own and no longer effectively implements the policy concerns that gave its birth." Id at 9-10.

123 This argument should be distinguished from a claim that a statutory grant of jurisdiction leaves the state with an insufficient interest in its own processes to justify abstention. Such a claim 
tended, calling into question the validity of the courts' decisions to abstain in ICARA cases without considering whether Congress had spoken directly on the issue.

\section{The plain language of ICARA.}

As an initial matter, the plain language of the statute provides little guidance, revealing only that actions shall be maintainable under the "concurrent jurisdiction" of state and federal courts. ${ }^{124}$ Further, the statute recognizes that ICARA may be applied without regard to whether a court from the child's home country has already issued an order granting formal custody to one of the parties. ${ }^{125}$ This suggests that Congress recognized the likelihood that abductions would occur in anticipation of a custody battle, but it is hardly determinative of where the claim should be maintained after a parent files for custody in state court.

Congress could have added a provision to ICARA that instructed federal courts not to abstain for any reason. It did not. The inquiry could end here, with a firm rule that permits abstention whenever Congress's grant of jurisdiction does not specifically preclude abstention. Going forward, the certainty that this rule provides would be appealing.

But to apply such a strict requirement to ICARA, a statute that was drafted in 1988, proves too much. To do so, courts would first have to assume that Congress either knew, or should have known, that it needed to insulate its grant of jurisdiction from Younger to make it effective in all cases. As noted in Part III.A, it is not clear that Younger even applies to a cause of action such as this one, where the claim is not constitutional in nature. There is no reason to presume that fourteen years ago Congress should have thought that a Youngerdefeating provision was even relevant to a specific grant of jurisdiction, let alone that such a provision was necessary. Therefore, the inquiry should be broadened to examine whether other sources can demonstrate that Congress did indeed intend to make federal courts available to hear ICARA claims that interfered with state processes.

2. The terms of the Hague Convention.

A second indication of Congress's intent could be the Hague Convention itself, which ICARA was enacted to implement. The official report of the Convention makes it clear that Hague petitions are

\footnotetext{
was rejected by the majority in NOPSI, 491 US at 364-65, and is not advocated here.

12442 USC \& 11603(a).

125 See 42 USC \$ 11603(f)(2) (providing that wrongful removal includes a "removal or retention of a child before the entry of a custody order regarding that child").
} 
intended to prevent the abduction from resulting in an illegitimate and artificial custody determination, ${ }^{126}$ and to increase the possibility that a final decision on custody will be made in the child's preabduction country. ${ }^{127}$ Additionally, the Convention contains a provision that instructs the courts of contracting states not to issue a custody ruling until after the abduction claim has been resolved. ${ }^{128}$ The treaty, however, does not consider the methods contracting states may choose to reach this end. It therefore provides no guidance on the question of why federal courts were given concurrent jurisdiction with their state counterparts under ICARA, or whether abstention is appropriate. $^{12 \%}$

3. The relevant legislative history.

A third source that may determine whether Congress understood that its grant of concurrent jurisdiction would have the effect of causing federal courts to interrupt state processes is the available legislative history. On its own, legislative history cannot clearly establish a particular legislative "intent." However, the information is at least probative and suggests that the drafters of ICARA understood that it would require federal courts to interfere with state processes.

The statute's jurisdictional grant was revised several times before ICARA was passed. As originally introduced, HR 3971 provided for concurrent jurisdiction in state and federal courts. ${ }^{130}$ This was changed by the Committee on the Judiciary to expressly provide for original jurisdiction over Hague claims in the state courts, with federal jurisdiction existing only to the extent that there were federal questions or diversity. ${ }^{131}$ It was in this form that ICARA was originally passed by the House.

The language granting "concurrent jurisdiction" over ICARA claims to state and federal courts ${ }^{132}$ was then reintroduced as the Senate's sole amendment to the House bill. ${ }^{133}$ According to Senator Dixon,

\footnotetext{
126 See Perez-Vera Report at 111 14-15 (cited in note 32) (noting that if the abductor cannot legalize the situation he has brought about through a custody proceeding, he would still maintain a forum advantage if the custody proceeding was heard).

127 See id at II 16.

128 See Hague Convention at Art 16 (cited in note 2) ("[T]he judicial or administrative authorities of the Contracting State to which the child has been removed ... shall not decide on the merits of rights of custody until it has been determined that the child is not to be returned.").

129 See, for example, Perez-Vera Report at II 44 (cited in note 32) ("[I]t is for the appropriate authorities within each State to decide questions of custody and protection of minors.").

130 See HR Rep No 525, 100th Cong, 2d Sess 7-8 (1988).

131 See id.

13242 USC \$ 11603(a).

133 See 134 Cong Rec S 6482 (Apr 12,1988) (Sen Dixon) (explaining that the purpose of his amendment was to avoid extensive litigation on the question of federal jurisdiction).
} 
who drafted the Senate's amendment, the House version had originally been written to limit access to federal courts "out of concern that these cases would embroil the Federal courts in deciding child custody matters." 134

In contrast, Senator Dixon argued that the statute was sufficiently narrow to prevent federal courts from deciding those issues. He sought instead to insert language that made it clear that federal courts were an appropriate forum for hearing abduction claims. ${ }^{1.5}$ The goal was to create a set of clear and consistent procedures for implementing the Hague Convention, and expressly provide the intent of Congress on the question of jurisdiction. ${ }^{136}$ In all cases, the petitioner would be allowed to choose either a federal forum or a state forum. ${ }^{137}$

In the House, several representatives spoke in support of the version passed by the Senate, indicating their belief that it was not an unwarranted intrusion on state processes to permit federal courts to entertain abduction claims, even though it was recognized that state courts had long held dominion over child custody issues. ${ }^{1.3}$ Representative Cardin affirmed this intention during his statement on the floor of the House: "In the special circumstance where international child abduction is alleged, both the Federal and State courts should be available to resolve the claims." ${ }^{\text {,139 }}$ Moreover, the simplified language had the advantage of preventing "litigation over whether Federal or State court jurisdiction is most appropriate in a particular case," thus expediting the resolution of the abduction claim.

The opposing view was represented in the Senate debate. Senator Hatch noted the overlap between the objects of the treaty and child custody matters, calling the decision to vest concurrent jurisdiction in federal and state courts a "close call." ${ }^{\text {,41 }} \mathrm{He}$ stated that several organizations had contacted him and expressed their preference for giving state courts exclusive jurisdiction over ICARA claims and that he had "closely examine[d] the issue." ${ }^{142}$ In response, Senator Dixon assured

134 Id.

135 See id (urging the adoption of the amendment because it contains "clear language on this sensitive matter of jurisdiction").

136 See id (Sen Dixon).

137 See id at S 6484 (Sen Dixon) (responding to a query by Senator Hatch of whether there were "any circumstances where such a choice is not available").

138 See, for example, 134 Cong Rec HR 8558 (Apr 25, 1988) (Rep Hughes) ("It does not remove from the States ... jurisdiction over a child, custody and care."); id at HR 8559 (Rep Cardin) ("Congress reaffirms its view that States have traditionally had, and continue to have, jurisdiction and expertise in the area of family law. Here we are not intruding into this jurisdiction.").

139 Id at HR 8559.

140 Id.

141134 Cong Rec at S 6483-84 (cited in note 133).

142 Id. 
him that the bill had been drafted to limit the courts' jurisdiction to only those issues specifically addressed by the Hague Convention. ${ }^{143}$ Senator Hatch later supported the bill.

Taken as a whole, the legislative history suggests that some members of Congress were aware of the possibility that states might object to ICARA actions as an intrusion on the role they play in resolving custody cases. Nevertheless, Congress provided a federal forum for those actions. The district courts that abstained from ICARA claims, however, fail to even consider this possibility. ${ }^{14}$ Instead, those courts merely note the variety of ways in which ICARA claims implicate state interests. ${ }^{145}$ Under this approach, it does not matter whether Congress has already made the "close call," because district courts will simply second-guess it or, worse still, ignore it altogether. This authority goes far beyond the federal courts' equitable discretion as envisioned by the Supreme Court. ${ }^{14}$

It is not the province of the courts to mention the existence of one of the factors that Congress considered relevant on one side of the jurisdiction debate and then refuse to give effect to a congressional determination that other factors carry sufficient weight to make federal courts an appropriate forum for these claims. ${ }^{147}$ While one

143 See id at $S 6484$.

144 Courts need not conduct such an inquiry in all cases. The possibility of a congressional directive to refrain from abstention only arises when the federal claim is statutory. Therefore, this Comment suggests the following rule: Courts should be considered on notice of a congressional intention to preclude abstention if (1) the regular operation of a statute has the tendency to interfere with state processes, and (2) the same statute includes a provision conferring federal court jurisdiction. See also Redish, 94 Yale L J at 78-79 (cited in note 115) (arguing that proponents of abstention should have the burden of proving that Congress did not intend to have its jurisdictional grants enforced).

145 See, for example, Bouvagnet, No 01-3928, slip op at ("Hague Convention petitions unquestionably 'raise issues which involve domestic relations,' which is a state interest."), quoting Gerbatsch, No 99-CV-728-J, slip op at 6; Silverman, No 00-2274, slip op at 7 ("The state court has awarded Mrs. Silverman temporary custody, appointed a guardian ad litem for the children, and ... prohibit[ed] their removal from the United States.").

146 See Quackenbush v Allstate Insurance Co, 517 US 706, 732 (1996) (Scalia concurring) ("If the court today felt empowered to decide for itself when congressionally decreed jurisdiction constitutes a 'serious affront' [to federalism] and when it does not, the opinion would have read much differently."), quoting id at 733 (Kennedy concurring). In Bouvagnet, the Seventh Circuit comes close to evidencing the same view when it notes that abstention is inappropriate in part because "an action under the ICARA implementing the provisions of the Hague Convention actually contemplates that a successful action might well result in the displacement of a custody decision in the state to which the child wrongfully has been taken." No 01-3928, slip op at 12.

147 One factor favoring the use of the words "concurrent jurisdiction" is the desire to eliminate needless litigation, exemplified perhaps by the cases considered here, over whether a federal forum was appropriate in particular circumstances. See 134 Cong Rec at HR 8559 (Rep Cardin) (cited in note 138). Additionally, there is anecdotal evidence suggesting that the term "concurrent jurisdiction" was supported by the State Department. See 134 Cong Rec at HR 8557 (Rep Frank) (cited in note 138). See also Grieve v Tamerin, 269 F3d 149, 153 (2d Cir 2001) (noting that the interpretation of a foreign treaty implicates important federal interests). 
might argue that this record does not establish such an intent, the district courts that have abstained from ICARA claims have not yet considered the possibility.

\section{Younger Abstention Is Inappropriate When the Federal Claims Could Not Have Been Brought as a Defense to the State Action}

The Younger doctrine's concern about federal courts' interference in state processes is not at issue in ICARA cases. When an ICARA claim is raised, the state custody action must be stayed under the terms of the statute, regardless of whether the ICARA claim is raised in state or federal court.

Younger abstention is ordinarily justified on the ground that federal courts should not exercise their equitable powers in such a way as to undermine legitimate state processes. In NOPSI, Justice Scalia characterized Younger as an exercise of the federal courts' power to withhold authorized equitable relief when it would unduly interfere with state proceedings. ${ }^{143}$ In Quackenbush v Allstate Insurance Co, the Court held that it was impermissible under Younger to dismiss an action seeking nondiscretionary relief. ${ }^{1.9}$

State interests are not served when, as with ICARA, the federal claim is specifically designed to have the effect of interrupting a state process. As argued in Part I.B, a primary goal of the Hague Convention is to prevent an abducting parent from using the laws of a chosen forum to "legalize" a custodial relationship with the abducted child." To further this goal, ICARA establishes procedures for returning an abducted child to her habitual residence before local courts can issue a custody ruling in the form of a separate hearing on the issue of abduction. ${ }^{151}$

Thus, if a federal court hears these claims, it will ultimately cause the custody dispute to be halted pending resolution of the abduction claim. If, on the other hand, the federal court abstains, and the abduction claim is heard in state court, the same result will occur: The custody claim will not be able to proceed until the abduction question is settled under the terms of the Hague Convention. ${ }^{152}$ This is because the

\footnotetext{
148 See 491 US at 359 (arguing that the power to abstain is part of the common law background against which statutes conferring jurisdiction are enacted).

149 See 517 US 706, 730 (1996) (explaining that abstention has been extended not only to cases arising under equity, but also to all cases in which the federal court is requested to supply some sort of discretionary relief).

150 See Perez-Vera Report at II 16 (cited in note 32).

151 See Blondin v Dubois, 189 F3d 240, 245 (2d Cir 1999) (noting that, under the Convention, the court lacks power to adjudicate the custody claim prior to deciding the abduction issue).

152 See Hague Convention at Art 16 (cited in note 2).
} 
Hague Convention requires the abduction claim to be resolved before local courts issue a final custody order. ${ }^{153}$

Worse still from the perspective of administering state processes, if the court determines that the child was wrongfully abducted, she will be returned to her home country. This terminates the state custody action altogether, regardless of whether the abduction claim is resolved in state or federal court. ${ }^{1.4}$

Hearing an ICARA petition, and granting the mandatory relief that it requires, ${ }^{155}$ interferes with a custody dispute, but it does so by congressional design in an attempt to implement the Hague Convention. In contrast, a federal court abstaining under Younger does so in order to prevent a defendant in state court from using the equitable powers of the federal court to cause an illegitimate interruption in state processes. For example, when John Harris felt that California was prosecuting him under an unconstitutional law, he could have raised this claim as a defense to the state criminal proceeding without asking a federal court to enjoin the state court. ${ }^{156}$ By abstaining, the Supreme Court ensured both a fair hearing for Harris's claim and a continuation of the state process without interruption. ${ }^{157}$

However, when a federal right can only be exercised in a separate proceeding, whether in state or federal court, there is no occasion for courts to think that their equitable powers are being used illegitimately, or as an affront to state processes, when they entertain these claims. The interference with state custody proceedings does not occur under ICARA because the courts are permitting an illegitimate attempt to derail state proceedings. ${ }^{1 . s}$ Rather, the disruption occurs because the United States and the other signatory nations of the Hague Convention have determined that custody hearings should not go forward until the abduction issues are settled. Federal courts should not be leery of exercising their jurisdiction for that purpose, regardless of whether it interferes with a state interest.

153 See id.

154 See id at Art 12; 42 USC \$ 11601(a)(4) (1994). See also Blondin, 189 F3d at 245 (holding that abducted children must be returned unless one of four narrow exceptions applies); Friedrich v Friedrich ("Friedrich II"), 78 F3d 1060, 1067 (6th Cir 1996) (same).

155 See Silverman, 267 F3d at 792.

156 See Younger, 401 US at 49.

157 See id. See also Midwestern Gas Transmission Co v McCarty, 270 F3d 536, 537 (7th Cir 2001), in which Judge Richard Posner expressed this view:

States oughtn't to be impeded in their efforts to enforce their own laws in their own courts and administrative agencies by injunctions issued at the behest of defendants in state proceedings who, seeking to delay and if possible derail those proceedings in midcourse, run to a federal court for an injunction against the continuation of the proceeding.

158 See Midwestern Gas, 270 F3d at 537. 
Abstention in ICARA cases has one result that could be said to advance comity and "Our Federalism": ${ }^{159}$ It allows a state court to determine whether the child was abducted and whether she should be returned. Although the identity of the forum does not prevent the custody hearing from being enjoined, or possibly dismissed altogether, allowing state courts to enjoin their own processes arguably promotes comity.

This does not mean, however, that this more limited advancement of comity should trump a parent's statutory right to a federal forum. Justice Black's opinion in Younger stressed that the Court did not advocate blind deference to states' rights, only a policy by which courts refrain from unduly interfering with state processes. ${ }^{160}$ In later decisions, the court explains that abstention remains "the exception, not the rule," and that federal courts retain a "virtually unflagging" obligation to adjudicate claims within their jurisdiction. ${ }^{161}$ This would hardly remain the case if federal courts were able to abstain, not on the grounds that they were interfering with state processes, but rathereven though interference was mandated by federal law-because states would prefer that only the states interfere with their own proceedings. Regardless of whether this interest is ultimately determined to be sufficient to justify abstention, courts should, at a minimum, pause to consider the extent to which this result furthers "Our Federalism."

\section{CONCLUSION}

Federal court abstention in cases brought under ICARA is inappropriate. Federal courts have so far failed to consider whether Congress's grant of specific jurisdiction over these claims precludes resort to abstention doctrines. This represents a failure to acknowledge the power of Congress to establish jurisdiction over federal causes of action. Moreover, the principal reason cited in favor of this abstentionthe maintenance of comity between state and federal courts, by recognizing and respecting the important state interest in child custody

\footnotetext{
159 See text accompanying notes 11-17.

160 See 401 US at 44.

161 NOPSI, 491 US at 359.

162 In making this determination, courts should also consider how much they should value the interests of our international treaty partners under the Hague Convention. To date, the Supreme Court has not applied Younger to a case arising under a treaty. Lower courts' application of Younger in treaty cases has been limited to the context of treaties with Indian tribes. See, for example, Morrow v Winslow, 94 F3d 1386, 1397-98 (10th Cir 1996) (applying the Younger doctrine to abstain from hearing a Native American father's challenge to state adoption proceedings). Relevant to the courts' determination might be the extent to which having a federal forum for ICARA claims promotes international comity between the United States and its treaty partners.
} 
matters-is not served by abstention. The primary purpose of the Hague Convention, and its implementing statute, ICARA, is to stymie an abducting parent's attempt to use local tribunals to establish artificial custody rights over an abducted child. To meet this goal, ICARA actions must, on some level, interfere with the ability of state courts to adjudicate custody disputes.

Congress, in creating this cause of action and making it maintainable in both federal and state courts, considered the question of whether it ought to be more deferential to state interests and gave a limited grant of jurisdiction to both state and federal courts. Congress's decision to make federal forums available for ICARA claims should not then be negated by federal courts merely upon the observation that these causes of action implicate important state interests.

Additionally, abstention in these cases does far less to promote comity than other types of Younger abstention. Since the state custody proceeding will be enjoined regardless of where the ICARA claim is heard, there are only limited grounds for concluding that "Our Federalism" will be advanced by eliminating a parent's right to choose a federal forum to determine whether a child was abducted. 


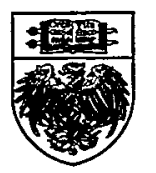

